\title{
BUZINKAY PÉTER
}

\author{
FIDELIS PANNONIA
}

\section{POLITIKAI PROGRAMKÉP 1792-BÖL IGNAZ PFEILHAUER ÜVEGHÁTLAP-FESTMÉNYÉN}

Budapesti magántulajdonban található az az üvegkép, melyet tulajdonosa dr. Borsos Béla (Beregszász, 1913 - Budapest, 1991) építész-múvészettörténész, főleg iparmúvészeti jellegú mügyüjteményéböl ${ }^{1}-a$ gyưjtő családjától, ajándékozás révén - szerzett meg. ${ }^{2}$

A $300 \times 350 \mathrm{~mm}$ méretü, $2 \mathrm{~mm}$ vastagságú üvegtáblára festett kép egy hazánkban kevéssé ismert technikával készült: üveghátlap-festés („Hinterglasmalerei”), ráadásul ötvözve árnyképes ábrázolással (,Silhouette”), továbbá ráragasztott hajszálvékony, majd karcolt vonásokkal részletezett arany- és ezüstalappal (fóliával) is díszítették („Églomisé”). A képet tehát az üveg hátoldaláról festették, fordított sorrendben, hogy az egymásra kerülö, karcolással is finomított rétegek a megfelelő kompozíciót adják ki. Ennek megfelelően a nyilvánvalóan metszetes vagy árnyképes előképek felhasználásával megfestett egész alakos árnyképes portrékon a ruha gombjait, szegélyeit és további belső részleteit a festékbe karcolta a művész, majd leheletvékony aranylemezzel borította vagy világosabb szürke, illetve vörös színnel megfestette. Így a képen a vékony vonások mint finom arany, szürke vagy vörös vonalak jelennek meg. ${ }^{3}$ Ugyanezen a módon, csak éppen fordított sorrendben készültek az aranyalapú díszítőelemek is: a függöny redői, az asztal, a székek, a tükör feletti magyar címer és a falon látható tájképek is. Itt az üvegre rögzített vékony aranylemezt karcolta a múvész a kívánt minta szerint, majd az ezt borító fekete réteg adta meg a végleges látványt. A festés és a fémfólia alkalmazása mellett még egy további sajátos eljárás is megjelenik a képen: a rajta látható alakok kezébe kisméretű (valódi) papírlapok vannak beillesztve, rajtuk tintával rövid, párszavas feliratokkal. Bizonyára ez is az oka annak, hogy az üvegképet a hátoldalán a szé- lein - vászondarabbal - hozzá rögzített (modern) kartonlap borítja. A hátsó borítólap így nemcsak a festék és a fémfólia rétegeket védi, de az alakok kezében tartott papírlapokat is rögzíti.

A kép négyalakos, belső térbe helyezett, szimmetrikusan felépített jelenetet ábrázol (1. kép). A középtengelyt egy - a lábai közti keresztlécen „F II" monogramos címerpajzzsal díszített - konzolasztalon álló, késő barokk asztali óra ${ }^{5}$ és mögötte a nagy álló, téglalap alakú fali tükör alkotja. A tükröt függöny redői övezik, melyet kétoldalt kiálló lándzsákra tüztek. Fent, a középtengely folytatásaként, a tükör felett, a függöny előtt a német-római császári koronával megkoronázott kétfejű sas, a Habsburgok címerállata látható, mellén a magyar címerrel. A helyiség padlóját - kissé torz - perspektívában ábrázolt, világosabb és sötétebb zöld, négyszögletes lapokból váltakozva kirakott burkolat borítja. A fal lábazatát rózsás díszítősáv alkotja, felette a szoba falát egyenletes, kissé zöldesebb aranyszín borítja, melyet a tükör két oldalán egy-egy fekvő téglalap alakú, egyszerü kerettel ellátott tájkép díszít. Fent és a kép két szélén a függöny bojtos zsinórokkal behúzott, redőzött vonalai képezik a képtér határait. Az asztal két oldalán, egymással szemben, széken ülő fiatal férfi- és nőalak, mögöttük egy-egy további álló, idősebb és fiatalabb férfi. Ruhájuk és hajviseletük a 18. század végének divatját idézi. Az árnyképes, bal-, illetve jobb profilból ábrázolt egész alakos figurák egymás felé fordulnak, és kéz-, illetve testtartásukból megítélhetően beszélgetnek. Erre utal a kezükben tartott latin nyelvü, feliratos papírlap is. Bal felöl haladva az első alak egy főpapi ruházatú idős férfi, mellén a Magyar Királyi Szent István Rendnek a széleken zölddel szegélyezett vörös nyakszalagján függő nagykeresztje, alatta 


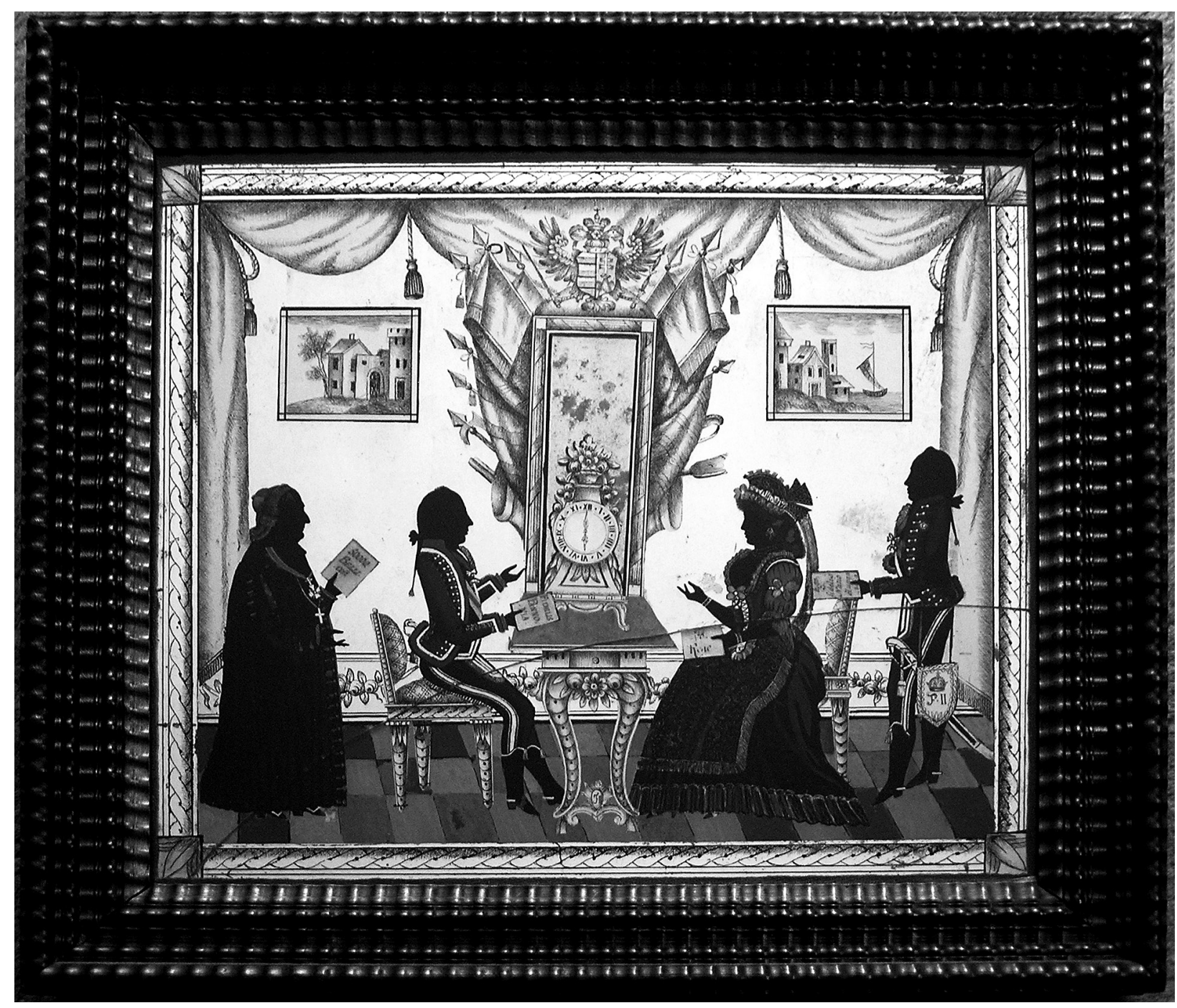

1. Ignaz Pfeilhauer: Politikai programkép az 1792-es budai országgyúlés idejéböl: I. Ferenc, Sándor Lipót nádor és Batthyány József esztergomi érsek egyezsége. Üvegkép, vegyes technika. Budapesti magántulajdon. A szerző felvétele

püspöki mellkereszt. Kezében a feliratos papíron: „50000. / BELLI / cor.", azaz „50 000 katona”. ${ }^{6}$ Előtte az asztalnál egy fiatal, előkelő férfi ül, ruházata a jellegzetes prémmel szegélyezett magyaros, zsinóros mente, csizma, nyakában pedig az Aranygyapjas rend jelvénye lóg, mellén keresztben a nyitott mente alatt a Magyar Királyi Szent István Rendnek a széleken zölddel szegélyezett vörös vállszalagja. Feliratos papírján „FIDELIS / PANNO / NIA.”, azaz „A hüséges Pannonia” szöveg áll (2. kép). Az asztal túloldalán fiatal nőalak ül, ugyancsak előkelő, de jellegzetes magyaros viseletben, szoknyája felett finom selyemből, illetve csipkéből dúsan hímzett kötényt visel, fején párta. Kezében a papíron - töredékesen olvasható - „Pr. Rege”, azaz „A királyért” felirat áll. A jobb szélen álló fiatal, ugyancsak előkelő ruházatú férfi szintén prémmel szegélyezett magyaros, zsinóros mentét és csizmát visel, nyakában az Aranygyapjas rend jelvényével; alatta keresztben, a nyitott mente alatt a Magyar Királyi Szent István Rendnek a széleken zölddel szegélyezett vörös vállszalagja, bal mellén egy díszített középmezős, sugaras kitüntetés, mely a Magyar Királyi Szent István Rend nagykeresztjének textilcsillagával azonosítható. ${ }^{7}$ A férfi oldalán magyaros szablya lóg, elötte a huszárok viseletéról ismert tarsoly, rajta „F II" monogram, felette a magyar Szent Korona régi ábrázolásával. Bal kezében, melyet az előtte álló szék támláján nyugtat a feliratos papíron „Ego / Fidelis / Natio / Hunga / rica", azaz - a magyarra nehezen fordítható - „Hüséges magyar nemzet (vagyok)" mondat olvasható.

A képnek kettős kerete van. Magán az üveglapon, a hátoldalon karcolt ezüst és aranylap technikával fonatos, a sarkokon leveles elemmel díszített sáv fut körbe. Az üveglapot, amely sajnálatos mó- 
don eltört, egy további üveglap mögé helyezték, s fából, szerszámmal megmunkált, ismétlődő, hullámos díszítésü, mély barnára fényezett és részben aranyozott díszkeretbe illesztették, majd hátul fa zárólappal borították. (A fa tagozatok ilyenfajta díszítése, a hullámléc a bútormüvességben és a képkeretezésben is a 17. század óta ismert és alkalmazott eljárás. $)^{8}$ Fa díszkerete feltehetően eredeti, az üvegképpel egy időben, annak befogadására készült.

A képen további felirat vagy müvészre utaló jelzés nem látható, de stílusa jellegzetes klasszicizáló késő barokk, „copf”, amelynek időszaka az 1790 körüli évekre esett. A stíluskritikai elemzés mellett az alakok ruházata és hajviselete is meglehetős pontossággal határozza meg az üvegkép korát: az 1790 körüli években kellett készülnie. Az ábrázolt jelenetet szintén azonosítja az alakok európai divattól eltérő magyaros ruházata, jelvényei, valamint a képen a Habsburg-sas mellén ábrázolt magyar címer, a feliratok egyértelmü magyar vonatkozása, továbbá a két ízben megjelenő „F II” monogram. Utóbbi a korszak uralkodói közül Ferencre illik rá, aki magyar királyként I. Ferenc, míg német-római császárként és cseh királyként II. Ferenc néven 1792-ben foglalta el a trónt. Mint Habsburg főherceg és a trón várományosa már születésekor megkapta az Aranygyapjas rendet, 1792-től pedig mint apostoli magyar király a Magyar Királyi Szent István Rend nagymestere is lett. Az üvegképen a jobb szélen álló alakban - összehasonlítva a korabeli uralkodói portrékkal, valamint az Aranygyapjas Rend magyar lovagjainak igen rövid névsorával és a lovagok életkorával - egyértelmü, hogy I. Ferenc magyar királyt kell lássuk (3. kép). Az Aranygyapjas rend lovagjai között ugyanis ekkor csak két idős, már a hatvanas évei felé járó arisztokrata és a két Habsburg volt a magyar politikai élet szereplője: a király és testvéröccse, a nádor. ${ }^{9}$ Sándor Lipót (Firenze, 1772 - Laxenburg, 1795) főherceg a Habsburg-család tagjai közül elsőként került az ország nádorainak sorába, egészen fiatalon, még 1790-ben. Ugyanebben az évben ütötték ôt az Aranygyapjas rend lovagjává is, majd egy évre rá megkapta a Magyar Királyi Szent István Rend nagykeresztjét is. Az üvegfestmény bal képfelén ülő, Aranygyapjas rendjelet és a Magyar Királyi Szent István Rend vállszalagját is viseló, fiatal férfit tehát - az életkorokat is figyelembe véve - kizárólag Sándor Lipót nádorral azonosíthatjuk (4. kép). Hasonlóan könynyü dolgunk van a mögötte, a bal szélen álló, idős egyházi főméltóság azonosításával, akit az 1790 körüli időkben már hatvan év felett járó esztergomi érsek személyében határozhatunk meg. Gróf Batthyány József (Bécs, 1727 - Pozsony, 1799) 1776-tól töltötte be az esztergomi érseki széket, és az elsők

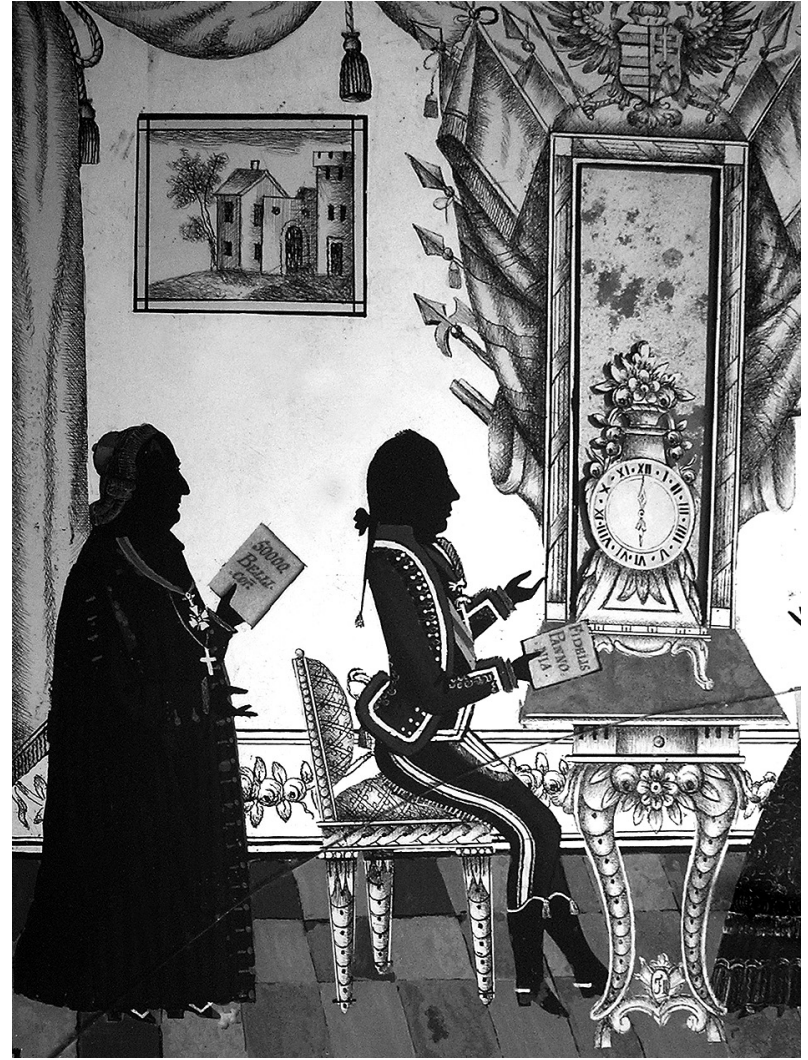

2. Ignaz Pfeilhauer: Politikai programkép az 1792-es budai országgyuulés idejéból: I. Ferenc, Sándor Lipót nádor és Batthyány József esztergomi érsek egyezsége. Üvegkép, részlet

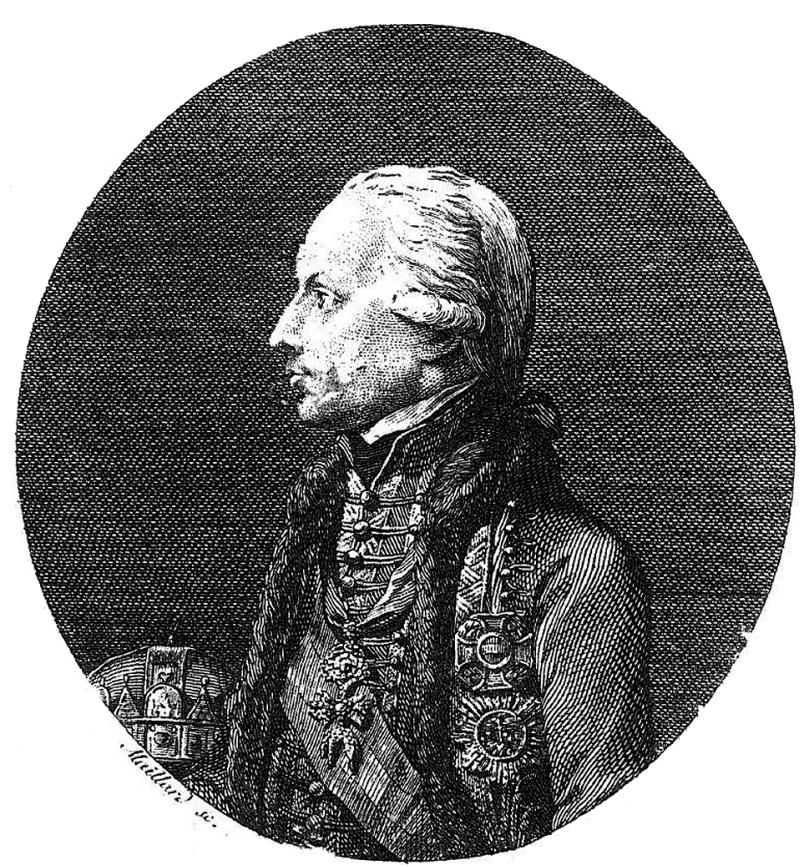

3. Ludwig Maillard: I. Ferenc magyar király, 1792. Rézmetszet.

Forrás: Magyar Hírmondó (Bécs) 1792. 1. szakasz 


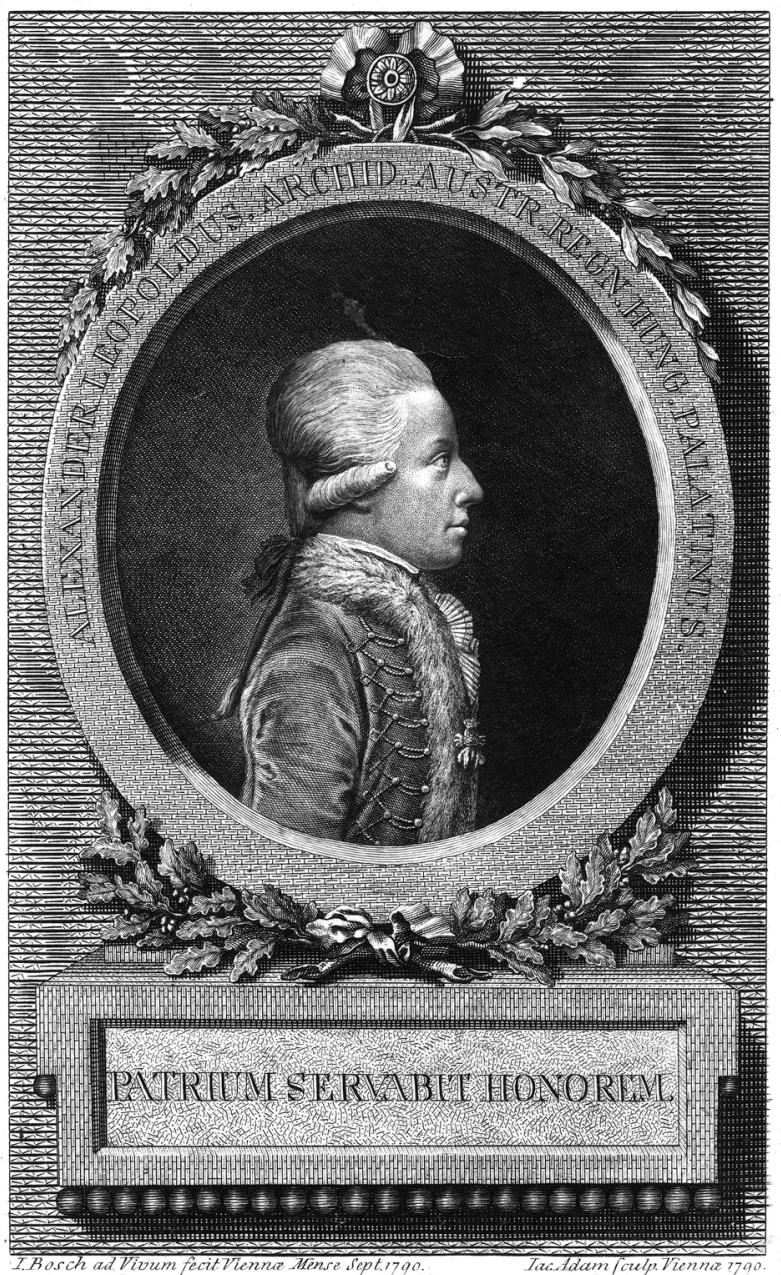

4. Leonhard Posch modellje alapján

Jakob Adam: Sándor Lipót nádor, 1790. Rézmetszet,

Magyar Nemzeti Múzeum, Történelmi Képcsarnok

között, még 1765-ben, az alapító Mária Terézia királynő nagymestersége alatt nyerte el a Magyar Királyi Szent István Rend nagykeresztjét. 1792-ben a magyar főpapok között más nem is birtokolta ezt (5. kép). ${ }^{10}$ Tekintettel arra, hogy a korszakban a női szerepeket egészen másként értelmezték, és nőket az ország főemberei között (pontosabban mellett!) csak feleségként találunk, itt is ezt kell feltételeznünk. Az ábrázolt alakok társaságába a történelmi körülményeket is figyelembe véve a királynét, Bourbon Mária Terézia nápoly-szicíliai hercegnőt (Nápoly, 1772 - Bécs, 1807) helyezhetjük be (6. kép).

Az üvegkép kora és az ábrázolt személyek alapján, a korszak eseményeit felidézve eljuthatunk a kép ideológiai programjához a „conceptus"-hoz is. Ehhez a fenti megállapítások alapján az 1792 körüli időszak eseményeit kell vizsgálnunk. Európa és a dunai Habsburg-monarchia számára ez az időszak a francia háborúk kezdetét jelenti. Bécs számára nemcsak a felforgató forradalmi eszmék jelentettek

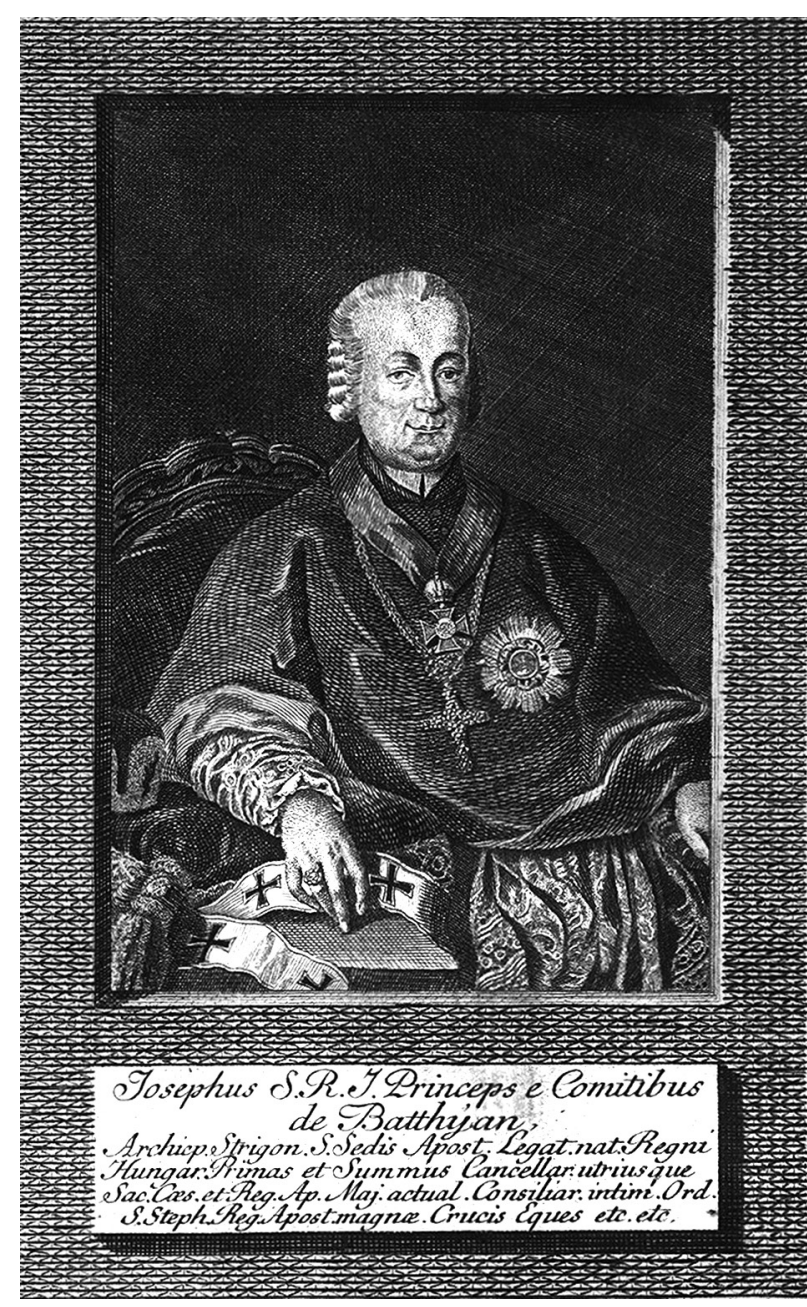

5. Johann Ernst Mansfeld Johann Michael Millitz festménye után: Gróf Batthyány József esztergomi érsek, 1790 körül. Rézmetszet

veszélyt, hanem Magyarországon a még csak két éve elhunyt, rossz emlékű kalapos király, II. József intézkedései is komoly ellenállást váltottak ki, a vármegyék, az arisztokrácia és a főpapok is mind erőteljesebben követelték a régi rend helyreállítását. 1792 áprilisában pedig a Habsburgok forradalomellenes szervezkedése is váratlan célt ért: maga a forradalmi Franciaország üzent hadat a bécsi uralkodónak. Számításba véve azt is, hogy a birodalom déli határain a törökkel még csak fél éve kötötték meg a békét, az uralkodónak komoly érdekei füződtek ahhoz, hogy birodalmában béke és a francia háborúban biztos hátországa legyen. A fiatalon, rövid uralkodás után 1792 márciusában váratlanul elhunyt uralkodót, II. Lipótot 24 éves fia, Ferenc József Károly osztrák főherceg (Firenze, 1768 - Bécs, 1835) követte a trónon, aki I. Ferenc néven magyar király, II. Ferenc néven pedig német-római császár és cseh király, 1804-től pedig - a német-római császárság megszüntével - I. Ferenc néven osztrák csá- 
szár lett. Az új uralkodóval szemben nagyok voltak az elvárások, a birodalom érdeke ismét a magyarokkal való kiegyezést kívánta. Szükség volt a háborúhoz a magyar korona országaiból származó újabb adókra, élelemre, s az újoncokra is. Ferenc ennek jegyében a magyar karok és rendek képviselőinek már Bécsben előre megígérte, hogy ő lesz az ősi alkotmány „legbuzgóbb őre”. 1792. május 24-ére, a magyar királyok régi székvárosába, Budára össze is hívta az országgyúlést, hogy ott azután a magyarok hagyományát követve királlyá koronázzák, s királyi hitlevelével eskü alatt ígérje meg a régi rend és szokások megtartását. Az országgyülésen Ferenc még további engedményeket is tett, így a kiegyezés gyorsan létre is jött. A „Tekintetes Karok és Rendek” ennek fejében a törvények közé cikkelyezték, hogy az uralkodónak „ötezer ujonczot, ezer lovat, négy millió forintot ajánlottak föl”. ${ }^{11}$ A kortárs beszámoló, a bécsi kiadású Magyar Hirmondó ${ }^{12}$ tudósítása érzékletesen festi le a nemesi mozgalom lelkesedését, a régi alkotmányos rend helyreállítását ígérő (sőt a rendek kérésére még tovább is módosított) királyi hitlevél kiadása feletti örömöt. "Júniusnak negyedik napja meg-érdemli, hogy ne tsak rend szerént való innepi veres; hanem arany betükkel jegyeztessen fel Magyar Ország Történetes könyvébe. Minekutánna t.i. felgyülekeztek vólna a Rendek ezen a' napon, délelőtti 10 órára a' Tek. Első Tábla' Palotájába, 's a' Gyülés Nádor-Ispány ő Kir. Fő-Hertzegségének elöülése alatt el-kezdődött: fel-olvasta eggyik Itélő-Mester Úr az ő Felsége által küldött Kir. Kötés-Levelet (Diplomát). - Jelentettük volt már, hogy az OrszágGyűlése, eleibe terjesztette vala Deputátusai által ő Felségének, hogy a' bóldogultt Fejedelem' Diplomájában elöl-forduló kétséges értelmü ki-fejezéseket, maga bölts itélete szerént jobittsa meg. Ezen kivánságát az Ország-Gyúlésének, úgy tellyesítette jó Királyunk említett Kötés-Levelében, hogy ezen kegyes Atyai tselekedetén egész indulásba jött a' Gyưlés, 's nem tsak a' maga ülö Palotáiában nyilatkoztatta ki különös örvendezések között, ő Felsége eránt tartozott háládatosságát; hanem minekutánna az Ország-Bírája, a' Personális, és Prímás ő Nagy Méltóságok igen szívre-ható Beszédeket tartottak volna: fel-kelt helyéből az egész Gyülekezet, 's a' Kir. Palotába indúlt (egynehány Méltóságokon kivül, mind gyalog mentek), hogy élö szóval hálálhassa meg, ő Felségének a' Magyar Nemzet eránt bizonyított szives hajlandóságát. A' Nagy Kir. Szálában tsak hamar meg-jelent a' F. Király, hív Országának kívánságára, a' midön meg-szóllalván Primás ő Eminen.ja, egy fontos rövidségü Deák Beszédben adta-elő a' Nemzet köszönetét. Az örömnek és szeretetnek édes indulatitól egésszen elfogódván a' Királyi Felség, tsak ezt mondhatta:

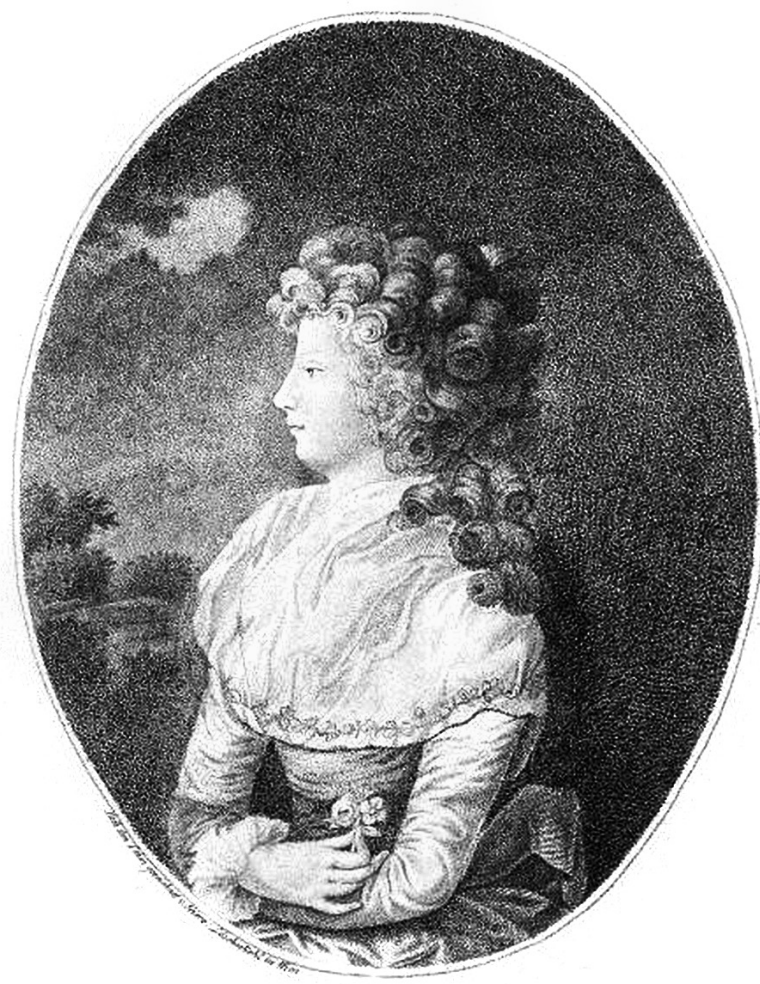

6. Johann Hieronymus Löschenkohl: Bourbon Mária Terézia nápoly-szicíliai hercegnö, 1790. Rézmetszet

»Nintsenek elégedendő szavaim, melylyekkel a' hív Magyar szívek által lett körülvétetésből származott örömömet vóltaképpen ki-fejezhesem; a' mit most érzek, irásban fogom közleni a' Nemes Hazával.« Ezzel ő Felsége, sok öröm-kiáltások, s' maga gyakori meg-hajtása között', ki-ment a' Szálából. - Buzgó örömben (enthusiasmusban) lévén az Ország, kívánta egy illy jó Szivü Királyának kedves Hitvesével, a' kegyes Királynéval is minden közbe-vetés nélkül tapasztaltatni, határt nem esmérő Szeretetét 's tiszteletét. A' Státusok' és Rendek' kérésére tehát, 's jó Nádor-Ispányunk' közbenjárására, meg-jelent a' Királyné is, egymást érő szives Éllyen kiáltások között. Prímás ő Eminentziája, tsak ott melegiben gondoltt elmés' Német Beszédben tette nyilvánvalóvá a' Magyar Nemzetnek, Királyné ő Felségéhez amint édes Annyához viseltető érzékenységét, 's állandó kegyességébe ajánlotta azt ő Felségének. A' Királyné, minden előre való hosszas gondolkozás nélkül, igen gyönyörüen válaszolt német nyelven, tiszta, 'és nagy fel-szóval a' Prímás' Beszédére. Kellemetesítették szép feleletét, ábrázatjának felgyúladása, melly, belső nagy megindulását jelentette; 's testének gyakori díszes meg-hajtása. A' kiben emberi érzékenység van, lehetetlen, lett vólna itt néki meg nem illetődni. Lett is olly öröm-kiáltás a' Királyné' kedves szavai végződésével, mellyet tsak a' hangjáról is lehetett esmérni, hogy az nem a' so- 


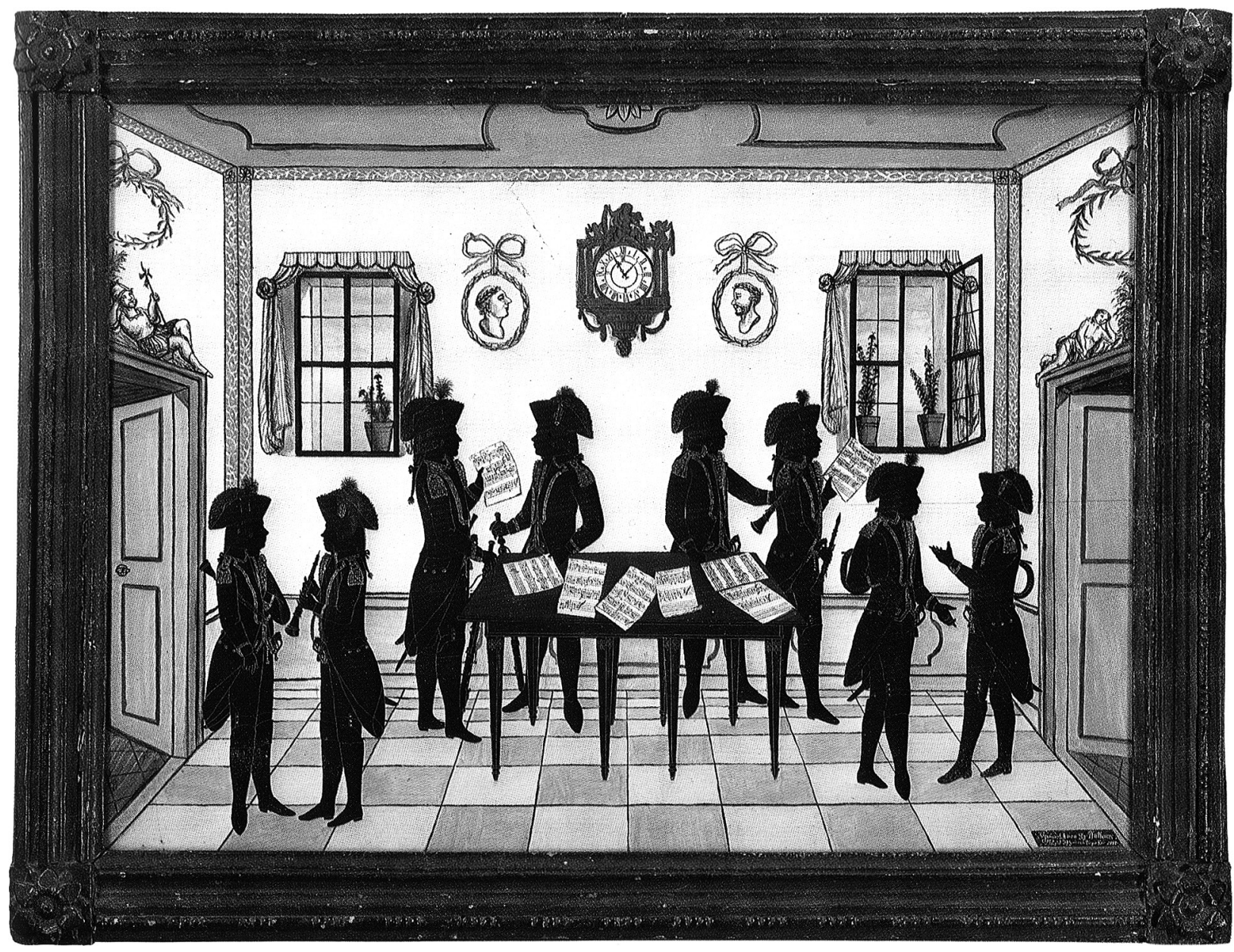

7. Ignaz Pfeilhauer: A linzi zöld egyenruhás polgárőrség kamarazenekara, 1796. Üvegkép, vegyes technika, jelzett. Linz, Oberösterreichisches Landesmuseum

vány tzeremoniának, hanem a' fel-buzdúltt szívnek szava. Erre, le-húzta kesztyüjét jobb kezéröl a' Királyné, 's kéz tsokolásra botsátotta magához minden válogatás nélkül a' jelenlévő Magyarságot."13 Az idézet nemcsak az eseményeket, a lelkesedéstől áthatott légkört, hanem a fő szereplőket is leírja, ezek a király, a nádor, a prímás (esztergomi érsek) és a királyné. ${ }^{14}$

Az üvegképünkön ábrázolt alakok előbbi azonosítását alapul véve, könnyen felismerhetjük az üvegkép jelentében az 1792-es év tavaszának budai eseményeit. Egészen pontosan azt az eseményeket egyetlen történésbe sürítő (képzelt) jelenetet láthatjuk, amikor a magyar karokat és rendeket képviselö nádor és a prímás-érsek a budai országgyúlés idején az ország hüségét és katonáit ajánlja az uralkodónak, aki ennek fejében azonosul a bátor (derék, becsületes, állhatatos) magyar nemzettel, megígérvén ősi rendjének fenntartását, $\mathrm{s}$ mindebben támogatásáról biztosítja ôt hitvese (azaz a család, vagyis a dinasztia). Feltétlenül meg kell azonban jegyezni, hogy a 18. század végén és a manapság haszná- latos nemzetfogalom jelentősen eltér egymástól. 1790 táján ugyanis még erőteljesen él a fél évezredes hagyomány, amely a nemzet fogalma alatt - az ősi „alkotmánynak” megfelelően - a nyelvi-etnikai hovatartozástól független, kizárólag rendi alapon szerveződő nemzet politikai közösségéhez tartozókat érti. ${ }^{15}$ Az itt ábrázolt jelenet, a nemzet („,natio”), Magyarország („Pannonia”), valamint az uralkodó is ilyen jelentéstartalommal olvasható. A képen ennek megfelelően a magyar történelemnek - az 1741es „életünket és vérünket” jelenete, és az 1867-es kiegyezés mellett - egy kevéssé ismert és számon tartott eseményét, az uralkodó és a nemzet közötti 1792-es kiegyezést láthatjuk. A királyi hitlevél nyomán a karok és rendek felajánlására az uralkodó nemcsak hogy elfogadó gesztust tesz, hanem egyenesen azonosul népével és nemzetével egészen odáig menően, hogy ezt egy erős latin mondattal hangoztatja is: „Ego fidelis natio Hungarica [sum]”. Ezt pedig úgy kell értelmezzük, hogy a király kinyilvánítja: semmilyen zendülés nem taszíthat le a trónról, mert én magam közületek való vagyok, tes- 
tem a nemzettest (is). Ezt még hangsúlyosabbá teszi a "fidelis"szó is, ami nem jelző, és még csak nem is a natióhoz tartozik, hanem minőséghatározóként az egót értelmezi: én, aki hüséges vagyok (szavahihető személy). És hogy mihez vagyok hüséges? Természetesen az alkotmányhoz! 1792-ben nem volt ennél fontosabb igazodási pont; minden társadalmi csoport ehhez viszonyítva határozta meg magát, és ezt kérte számon az uralkodótól is politikai programjában. ${ }^{16} 1792$ tavaszára ugyanis már az uralkodónak szövetségeseket kellett keresnie, s leginkább a vidéki nemességgel egyezett az érdeke: visszaállítani az alkotmányt, reformok nélkül. II. József kudarcba fulladt példája még eleven volt: a reformok kockázatot hordoznak, s olyan ellenállásba ütközhetnek, ami egy külső háború, s egy felforgató eszme elleni küzdelem során már nem vállalható fel. Az üvegképen megjelenő feliratok nyelvválasztásának is jelentőséget tulajdoníthatunk: a latin nyelv is a nemesnek volt kedves, mint konzerváló kulturális szimbólum. Kézenfekvő lett volna, ha a magyar megbízó anyanyelvén, magyarul íratja a szövegeket, vagy az üvegképet készítő, feltehetően bécsi müvésszel, németül. A latin is tehát tudatos választás eredménye lehetett tehát. ${ }^{17}$ Megállapíthatjuk, hogy a képi elemek, a feliratok és a mögöttes eszmék összességükben egy lehetséges nemzeti program irányába mutatnak: a rendi (köz)nemesi nacionalizmus hangja ez, ami semmi egyébbe nem kapaszkodott az alkotmányon kívül, amelyet sértetlenül kívánt viszszakapni, benne a kiváltságaival, reformok nélkül. Történelmi távlatokból visszatekintve láthatjuk, hogy az 1792-es események jelentőségét hamarosan elhomályosította több tényező is. Az ugyanekkor megkezdődött és több mint két évtizeden át húzódó francia háborúskodások, az 1795-ös Martinovics Ignác féle jakobinus összeesküvés, majd ezt követően a bécsi udvar abszolutisztikus intézkedései, és nem kevésbé a nemzet fogalmának a 19. század derekára végbemenő alapvető megváltozása mind az irányba hatottak, hogy az 1792-es eseményeknek a későbbiekre gyakorolt hatása elhalványult. Mindez, ahogyan látni fogjuk, üvegképünk készítési idejét is pontosan behatárolja.

Az üvegképet a korabeli politikai ábrázolásokkal, képi tudósításokkal összehasonlítva azt is megállapíthatjuk, hogy azon nem az 1792-es budai országgyülés idején megtörtént valós eseményt és helyszínt kell keresnünk. ${ }^{18} \mathrm{Az}$ épület belső terében, szimmetrikus elrendezéssel elhelyezett árnyképes alakok és a kiegészítő díszletek a korabeli politikai esemény-ábrázolás típusának felelnek meg. ${ }^{19}$ Sőt, a gondolatmenetet folytatva azt is kimondhatjuk, hogy nem az ekkor már elterjedt politikai tudósítások egy példájával állunk szemben, hanem üvegké- pünk valójában egy politikai programkép. A tudósításokra - a dolog természetéből fakadóan - a metszetes, olcsón sokszorosítható grafikai eljárásokat alkalmazták. ${ }^{20}$ Az üvegkép azonban mint technika e müfaj szempontjából túl bonyolult és költséges lett volna. Ebből viszont az is következik, hogy ezt a müvet nem a hírekre éhes polgárság vagy a világra nyitott nemesség számára készítették, hanem mögötte meghatározható személy, megrendelő kellett álljon. A lehetséges megrendelőt nyilvánvalóan nem a bécsi udvari körökben kell keresni, hiszen ott ez a kiegyezés sokkal inkább volt politikai kényszer szülte alku, mintsem örömteli esemény. Annál inkább üdvözölték az új királynak a magyar nemzet iránt kinyilvánított hüségét a „Tekintetes Karok és Rendek". A megrendelő tehát a magyar politikai élet felsőbb köreiből kerülhetett ki. Azon belül is az ősi alkotmányt védők - elsősorban vármegyei (köz)nemesi - táborából, ${ }^{21}$ hiszen a 18. század végére már megjelentek más irányú, az ősi alkotmánytól eltérő politikai nézetek is. Az alapvetően különböző szemléletmód miatt viszont sem a királyt és a királyságot elutasító republikanizmus, sem a felvilágosult abszolutizmus vagy a csinosodás („pallérozódás") hívei nem jöhetnek itt szóba. ${ }^{22}$ Irott források hiányában a megrendelő kilétét illetően azonban csak feltételezésekbe bocsátkozhatnánk. E kérdésben annál is inkább megfontoltnak kell lennünk, mivel sem a magyaros viselet, sem a politikai tartalom megjelenítése nem volt egyedülálló jelenség a korszakban. A jozefinista időkben szabadabbá lett sajtó és a nyilvánosság, a nemesi ellenállás ugyanis éppen ebben a rövid időszakban, az 1790es évek elején más időszerü politikai mondanivalóval felruházott müveket is szült Magyarországon. ${ }^{23}$

Az üvegkép alkotójának meghatározására - elsősorban a kiterjedtebb német és osztrák szakirodalom alapján - szintén kísérletet tehetünk. Elöljáróban feltétlenül meg kell jegyezni, hogy az üvegképfestés mint eljárás magyar földön ekkortájt, a 18. század végén nem tartozott az ismert és alkalmazott müvészi technikák közé. Az üveghátlap-festés Magyarországon csak a késői időkben, a 19. század második felében vált népszerü és szélesebb körben használt eljárássá. Azonban ekkor is elsősorban a népi vallásosság körébe sorolt szentképek, ikonok készültek evvel az eljárással, s azok is inkább a nemzetiségi (román, német, szlovák) területekhez kötődtek. ${ }^{24}$ Képünk alkotóját tehát távolabb, az országhatárokon túl kell keressük. Kézenfekvő, hogy az uralkodó székvárosában, Bécsben nézzünk körül, ahova a magyar előkelőségek is állandó bejárással rendelkeztek, s amely a magyarországi kulturális és müvészeti életnek ekkoriban amúgy is sok tekintetben 
a kiinduló-, illetve középpontja volt. Ezt a feltevést erősíti egyébként az is, hogy az üvegképünkön az uralkodó monogramját - következetesen kétszer is - nem a magyar számítás szerinti I. Ferenc, hanem az osztrák számításnak megfelelő II. Ferenc, azaz „F II” monogram formájában látjuk.

Tekintettel az üvegképen ábrázolt jelenet müfajára, elsősorban az árnyképkészítés történetében kell tájékozódnunk, majd ezt követően érdemes a bécsi feltevést közelebbről is megvizsgálni. Az árnykép divatja a 18. században Nyugat felől Keletre haladva hódította meg Európát: Angliából, majd Franciaországból kiindulva a 18. század közepén a német területeken, majd 1780 táján már Bécsben is hatalmába kerítette a felsőbb és - olcsó előállítási költségei miatt - a kevésbé tehetős társadalmi rétegeket is. ${ }^{25} \mathrm{Az}$ 1780-as években Európa-szerte a portrék, sőt portréalbumok mellett az árnyképes jelenetek is teret hódítottak: a főleg vándorművészek által készített csoportképeket, illetve családi jeleneteket mutató ábrázolásokkal egyidejüleg a politikai és társadalmi élet eseményei is árnyképekre kívánkoztak. ${ }^{26}$ A 18 . század végi Ausztriában és különösen Bécsben igen élénk árnyképkészítő munka folyt, nevesebb művészek mellett számos névtelen vagy akár alkalmi „művész” kezén. Sőt az egyik legjelesebb - kiadói tevékenységet is folytató - árnykép-müvész Johann Hieronymus Löschenkohl (Elberfeld, 1753 - Bécs, 1807) még az "Árnykép-gyáros" („Silhouettenfabrikant”) jelzőt is elnyerte. ${ }^{27}$ Ugyanakkor a bécsi árnyképkészítés sajátosságaként jegyzi a szakkutatás, hogy az árnykép kiszínesedik: a portrék és jelenetek háttere olykor aprólékosan kidolgozott, színesen megfestett részleteket is mutat. Mindez egyébként a továbbra is feketében megtartott árnyképes alakokkal együtt sajátos hatást keltett már a kortársakban is: mintha négereket („Negros”) láthattak volna a megszokott európai környezetünkben. ${ }^{28}$ Ez a kiszínesedés egyébként technikai értelemben is jellemzője lett a 18. század végi európai árnyképeknek: az 1790-es években - Angliából kiindulva - a fekete (vagy más egyszínű) körvonalba zárt alakok kezdtek feloldódni. Az alakok ruházatán vékony arany (vagy más) színü vonásokkal („pencilled with gold”) apró részletek jelentek meg: a gombok, szegélyek, paszományok és az egyetemi, vagy katonai egyenruhák, kitűntetések legapróbb részletei is élénk színekben pompáztak, hogy egyértelművé tegyék az ábrázolt társadalmi vagy katonai rangját és kötődéseit. Sőt, ez az árnyképábrázolás lényegével ellentétes törekvés tovább fokozódott az alkalmazott technikák és hordozók kiszélesedésével. Éppen ez idő tájt kezdtek ugyanis szélesebb körben elterjedni az üvegen, elefántcsonton és nemesfémtárgyakon alkalmazott árnyképes díszítések is. ${ }^{29} \mathrm{~A}$ budapesti üvegkép tehát jól illeszkedik az 1790-es évek bécsi árnyképei közé: színes enteriőrben látjuk a többalakos árnyképes jelenetet, az alakok ruházatán pedig a vékony arany, vörös vagy más színekkel meghúzott vonások érzékeltetik az apró, de lényeges részleteket.

Az üvegkép pontosabb meghatározása érdekében érdemes a jelenet témáját és ikonográfiáját, a politikai eseményábrázolás jellegzetességeit is alaposabban körüljárni. A politikai tartalmú események ábrázolása - akár tudósítás, akár szatirikus (gúnykép) jelleggel - ebben az időszakban Európában és természetesen a császárvárosban is már bevett müfajnak számított. Elég, ha a korszak magyar vonatkozású politikai tudósításai közül az egyik ismertebb képre, a magyar Szent Koronának a II. József általi 1790-es visszaadását bemutató - több változatban is ismert - metszetére gondolunk. ${ }^{30}$ Természetesen több rézmetsző és művész is alkotott ilyen müveket, melyekről leolvashatjuk az ábrázolási típus kötelező kellékeit: palota díszes termében, asztal körül, egymás felé forduló, kifejező mozdulatokkal, illetve álláspontjukat mutató rövid feliratokkal tárgyaló - ruházatukból láthatóan magas rangú férfialakok. ${ }^{31} \mathrm{E}$ sajátos müfajnak a korszakban legjelentősebb bécsi - távolabbi vidékeken, akár még Augsburgban is követőkre találó alakja az „árnyképgyáros” minőségében már említett Johann Hieronymus Löschenkohl. Löschenkohl mint metsző és kiadó a politikai és a társadalmi élet eseményeit megörökítő képein egy jellegzetes képi világot hozott létre: paloták vagy városi épületek tereiben, köztereken, parkokban találkozó árnyképes, metszetes, illetve utólag - részben vagy egészen kifestett többalakos jelenetek. Politikai tudósításai (,Bildreportage") között találunk több, csaknem azonos, szimmetrikus elrendezésü, szobában, teremben ábrázolt árnyképes jelenetet. ${ }^{32}$ Ezek között akad nem is egy, mely a budapesti üvegképünkkel olyan szoros - kompozicionális, formaképzési és tematikus - rokonságot mutat, hogy kézenfekvőnek tartanánk az ő müvei között keresni az üvegképünk helyét is. Ezt azonban el kell vetnünk, mivel Löschenkohl életmúve már több mint fél évszázada a szakkutatás figyelmének középpontjában áll, és a művész hagyatéki leltárát is ismertető, alapos feldolgozások, kiállítások, katalógusok egyike sem tud - az árnyképek, metszetek, kártyák, legyezők, kalendáriumok mellett - arról, hogy Löschenkohl vagy mühelye üvegképfestéssel is foglalkozott volna. ${ }^{33}$ A grafikai ábrázolások, illetőleg a lehetséges előképek kutatása kapcsán feltétlenül meg kell jegyeznünk azt is, hogy 1792-ből a magyarországi politikai élet eseményeiről már több ábrázolást is ismerünk: I. Ferenc, valamint felesége pár nap- 
pal későbbi koronázásáról, a koronázási esküről vagy a koronázást követő lovaggá ütésekről. ${ }^{34} \mathrm{Az}$ üvegképünkön ábrázolt 1792-es budai kiegyezés bármilyen további ábrázolását azonban sem közgyüjteményeinkben, sem a kor köztörténetét vagy képzőművészetét feldolgozó kiadványokban, de az interneten sem sikerült találni. ${ }^{35}$

$\mathrm{Az}$ árnyképkészítés és a sokszorosított grafika rövid áttekintése után rá kell térnünk - a velük egyébként szoros kapcsolatban álló - üveghátlapfestés területére is. Bár a szakkutatás e téren még sok részletkérdéssel adós, az elmúlt fél évszázadban itt is komoly átfogó és egyes részterületeket bemutató feldolgozások születtek, melyek a budapesti üvegképpel, készítésével, meghatározásával kapcsolatos technikai, művészettörténeti és földrajzi kérdéseket is segítenek megválaszolni. ${ }^{36}$ Sőt, ezek alapján az alkotómüvész kilétének meghatározására is kísérletet tehetünk.

Az üveghátlapfestés kapcsán érdemes néhány technikai sajátosságra külön is figyelmet fordítani. Az üvegképek készítői ugyanis igen gyakran nem új, önálló kompozíciókat alkottak, hanem metszetes előképek után dolgoztak. A szakkutatás üveghátlap-festők papírra rajzolt motívum-gyüjteményeit is ismeri, melyeket tetszőleges módon, részleteiben vagy egészben lehetett párosítani, így újabb és újabb változatokat, kompozíciókat létrehozni. Sőt mivel az üveg mint átlátszó hordozó ezt lehetővé tette: nem egyszer "csak” az üveglap mögé helyezett metszetes vagy festett előképek másolását végezték el. A másolómunkát segítette a 17. század elején feltalált mechanikus szerkezet, a pantográf vagy más néven gólyacsőr. Evvel a körzőre emlékeztető egyszerü eszközzel ugyanis bármilyen kompozíciót tetszőleges méretre át lehet rajzolni, és így a megfesteni kívánt üveglap méretéhez igazítani.

Az évezredes múltra visszatekintő üveg(hátlap) festés Európa számos üvegkészítő központjában - az antikvitást követően ismételten - a középkor végére igen magas technikai és müvészi színvonalra fejlődött. A reneszánsz és barokk időszakában a francia, angol és német üvegfestő központok mellett - az egyik legjelentősebb központtól, Augsburgtól Keletre - a keletbajor, osztrák és cseh területeken is komoly hagyományt teremtettek az üveghátlap-festők. E térség sajátosságaként ismeri a szakkutatás az üvegfestés és a karcolt fémfóliák („Hinterglasradierung”) együttes alkalmazását, egyfajta sajátos színes képi világot kialakítva. ${ }^{37} \mathrm{Az}$ üveghátlap-festés klasszikus szakirodalma a 18 . század végét már a technikai és müvészi hanyatlás időszakának tartja, mivel ekkor az üvegképeken egyre gyakoribbá válik a festés mellett vagy helyett különféle idegen anyagok (papír, vászon) beillesz- tése a képre. Emellett szélesebb körben is divattá válik a leheletvékony fémlapok, ezüst-, arany- és egyéb fémötvözet-fóliák alkalmazása is, kombinálva karcolásos eljárásokkal. Ugyanekkor, az 1790 körüli években az üvegképek ábrázolásain a papíralapú sziluett-képek divatja is áthat: az üvegképeken is árnyképes alakok jelennek meg. Szintén a 18. század végén és a 19. század elején az üveghátlapfestés divatja az udvari „magas múvészetből” elkezd kikopni, és egy jó évszázadra - szentképek és üvegikonok formájában - a népi vallásosság hordozójává válik. Az üveghátlapfestés tehát a képző- és iparmúvészeti szakkutatás tárgyából evvel átkerül a néprajztudomány körébe. Ugyanakkor a szakkutatás által kevésbé méltatott részterületként a „magas művészet” körébe sorolható üvegképek a polgári igények kielégítésére továbbra is készültek: a biedermeier időszakában számos polgári család csoportképe is így készült el Európa-szerte, Ausztriában, de Angliában vagy akár Dániában is.

A budapesti üvegképen megjelenik a kelet-bajor, osztrák és cseh területekre jellemző üvegfestés és karcolt fémfóliák együttes alkalmazása, tehát a korábbiakban említetteken túl a technikai szempontokra alapozva is - jól tesszük, ha üvegképünk alkotóját is e tájékon keressük. Ugyanakkor az üvegkép esetében sem tünik ésszerünek - a nehezebben áthidalható földrajzi távolságok, az ekkor már létező behozatali vámok miatt - távolabbi készítőt, művészt feltételeznünk. Ausztriában, Bécsben maradva az üvegkép-festők munkáit vizsgálva hamar ráakadhatunk igen közeli párhuzamként Ignaz Pfeilhauer (Linz, 1765 - Linz, 1843) - Bécsben is müködő linzi polgár ${ }^{38}$ - üvegképeire, különösen is a linzi zöld egyenruhás polgárőrség kamarazenekarát ábrázoló, 1796-os jelzett képére, melyet a szakkutatás már egy évszázada felfedezett (7. kép). ${ }^{39}$

Hasonló, szignált munkája Pfeilhauernek egy ismeretlen családot a reggeliző asztalnál ábrázoló üveghátlap-festménye 1794-ből. Itt is enteriőrbe helyezett, szimmetrikus felépítésü, asztal köré csoportosított, többalakos, árnyképes jelenetet láthatunk, néhol a budapesti üvegképpel megszólalásig azonos megoldásokkal. ${ }^{40}$ Kora, kompozicionális, technikai és múvészi megoldásai miatt - ha csak kérdőjellel is, de - Pfeilhauernek tulajdonítja a szakkutatás a felső-ausztriai Linz múzeumában őrzött uzsonnázó pár üvegképét is (8. kép). ${ }^{41}$ A szakkutatás ugyan még nem emelte be a feldolgozott üvegképek körébe, mégis hivatkozhatunk Pfeilhauernek egy további képére is, melyet a Bajor Televízió egy 2007-es adásában „Scherenschnitt - Um 1836, von Ignaz Pfeilhauer" címmel mutattak be. ${ }^{42}$ Ez bár az előbbi, még az 1790-es évek jellegzetes művészi stílusát idéző üvegképekhez képest vagy négy évti- 


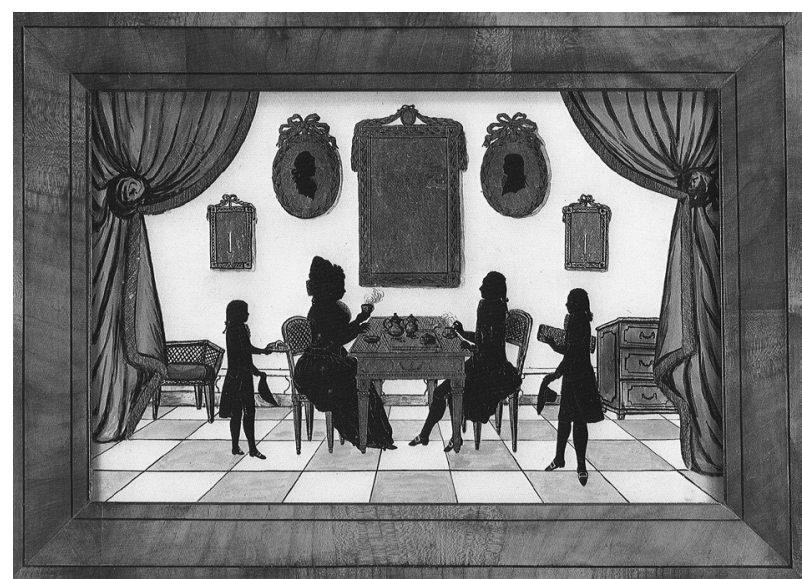

8. Ignaz Pfeilhauer: Család a reggeliző asztalnál, 1794. Üvegkép, vegyes technika, jelzett. Reprodukció

zeddel későbbi, mégis több részletében is egészen közeli hasonlóságokat mutat.

Ignaz Pfeilhauer előbb ismertetett üvegképei alapján - egy a kortárs üvegképektől jellegzetesen eltérő - önálló csoportot határolhatunk el. Ez az alapvetően a késő barokk - a bécsi árnyképkészítő Löschenkohlt idéző - művészetben gyökerező képi világ sajátos jegyeket hordoz, ezek: a térszerkesztés fogyatékossága, a vetett árnyékot nélkülöző, kissé mereven megformált árnyképes alakok, melyek mintha lebegnének, valamint, hogy a szoba és a berendezési tárgyak vonalai nem a perspektíva szabályainak megfelelő enyészpont felé tartanak. Az enteriőrbe helyezett csoportképek megjelenítése is közös jellemzőket mutat: a szögletes padlólapok váltakozó mintázata, a szimmetrikus elrendezésű szoba, középen asztallal, felette a falon órával vagy tükörrel, valamint jobbra és balra egy-egy képpel. A finom (arany- vagy más színnel meghúzott) vonalakkal a belső részleteket is megmutató árnyképes alakok beszélgetésre utaló kéz-és testtartása is hasonló. Ezt egészíti ki végül a színesen megfestett és a karcolt fémfóliákkal, valamint további „idegen anyagokkal" (vászon, papír) ötvözött készítési eljárás is, ami szintén közös jellemzője Pfeilhauer munkáinak. ${ }^{43}$

Ignaz Pfeilhauerról aránylag keveset tudunk, csupán négy, jelzettel ellátott és egy további, a szakkutatás által neki tulajdonított üvegképét ismerjük. ${ }^{44}$ Azon túl, hogy linzi polgár volt, de árnyképés üveghátlap-festőként Bécsben is müködött, ${ }^{45}$ valamint hogy a linzi levéltári iratok alapján anyakönyvi adatait is ismerjük, ${ }^{46}$ megállapításainkat képei alapján tehetjük. Mindezek alapján arra következtethetünk, hogy ugyan a polgári, és felsőbb társadalmi rétegek kiszolgálására (is) berendezkedett művész volt, de anatómiai és térábrázolási ismereteinek fogyatékossága a magasabb, akadémiai képzettség hiányát sejtetik. Képeinek forrását - nyilvánvalóan - a korszak divatos múvészei, metszetei, sokszorosított képei jelentették, így többek között a fentebb is említett bécsi Löschenkohl képei, nyomtatott lapjai, füzetei. Az 1790-es évekre keltezett munkái annyira korszerüek, a legfrissebb divatot követik, hogy azokat bécsi tartózkodásához kell kössük. Az anyakönyvek szerint viszont 1800 júniusában Linzben köt házasságot, ahol azután négy évtized múlva meg is hal. Az 1836-os évszámot viselő üvegképe ugyanolyan formai és technikai megoldásokat mutat, mint négy évtizeddel korábbi, az 1790-es években készített munkái. Ennek alapján azt sejthetjük, hogy a nemzetközi művészeti központtól, a császárvárostól már távol kerülvén, a linzi megrendelői kör hagyományosabb igényeinek megfelelően, régebbi stílusát megőrizve készítette üvegképeit.

Ignaz Pfeilhauer megismerhető munkáival való, a fentiekben ismertetett szoros technikai, kompozicionális, téralkotási és egyéb egyezések, hasonlóságok alapján a budapesti üvegképet is életmüvébe illeszthetjük, méghozzá pályájának korai, 1792-ben készített üvegképei közé. ${ }^{47}$

Összességében tehát megállapíthatjuk, hogy egy sok szempontból különleges és értékes üvegképet mutattunk be. Kivételesnek számít ugyanis már az is, hogy egy üvegképről ennyi mindent tudjunk, beleértve az ábrázolt jelenetet, az ábrázolt személyeket, a készítés évét, a megrendelői kört, sőt még az alkotóját is feltételezhetjük. Maga az üvegkép technikai szempontból is különleges, belső részletein finom vonásokkal kidolgozott árnyképes üvegképként is a legkorábbi datálható alkotások közé tartozik. Külön értékének tarthatjuk továbbá, hogy egy jelentős magyar történelmi eseményt ábrázol, amely alapján készítési kora is pontosan meghatározható. Emellett azt is megállapíthattuk, hogy egy korai, magyar megrendelésre készített politikai programképrő́l van szó: egy a készítés korában időszerü politikai célkitűzést jelenít meg a képző-, illetve az iparmúvészet eszközeivel. A magyar kötődések között kiemeljük a - csak töredékesen ismert provenienciát is: megrendelőjét, első tulajdonosát a kor magyar közéletének a vármegyei nemességhez igazodó szereplői között kell keressük, míg a kép történetének hozzánk közelebb eső végén egy jelentős hazai iparmúvészeti magángyưjteményt találunk. Ritkaságértékét növeli, hogy amennyiben meghatározásunk helytálló, a budapesti tárgy az Ignaz Pfeilhauerhez köthető üvegképek között az eddig megismert legkorábbi darab. ${ }^{48}$ 


\section{JEGYZETEK}

1 Takács Gábor: Mügyűjtők Magyarországon a 18. század végétôl a 21. század elejéig. Bibliográfiai lexikon. Kieselbach Galéria és Aukciósház, Budapest 2012, 91.

2 A kép korábbi, a 20. század közepét megelőző provenienciáját egyelőre nem ismerjük.

3 Német nyelvterületen, ahol az üveghátlapfestés és az árnyképkészítés jobban elterjedt, erre a különleges eljárásra még saját szakkifejezést is alkalmaznak: „nuancierte Silhouette".

$4 \mathrm{Az}$ üvegkép - a tulajdonos közlése szerint - az 1990-es évek második felében restauráláson esett át, ekkor derült ki, hogy a kép jobb oldalán ülő nőalak kezében levő papírlap sem veszett el, hanem csak elmozdult a helyéről, így az a restauráláskor az eredeti helyére visszailleszthetô volt.

$5 \mathrm{Az}$ asztali óra római számos számlapja éppen 6 órát mutat. Ennek esetleges jelentősége egyelőre nyitott kérdés. Feltétezésünk szerint az óra itt inkább csak dekorációs elem.

6 Egészen pontosan „50000 hadviselö lélek, egyed, újonc". A kisméretű papírlapokon több sorba osztott latin feliratok pontos fordításában, illetve értelmezési lehetőségeiben Király Erzsébet volt segítségemre. Ezúton is köszönöm neki.

7 A ruhára tüzött jelvény nem vehető ki pontosan, de a körülmények ismeretében a kitüntetés elmosódott formáiból és sugaras vonalaiból arra következtethetünk, hogy az a Szent István Rend nagykeresztjének a 18. században adományozott textilcsillaga lehet. Vö.: Gödölle Mátyás - Pallos Lajos szerk.: Szent István Lovagjai. A legrangosabb magyar kitüntetés 250 éve. Magyar Nemzeti Múzeum, Budapest 2014, 166-167.

8 Vö.: Kiss Eva szerk.: Bútorművészeti lexikon. Corvina Kiadó, Budapest 2005, 104.

$9 \mathrm{Az}$ aranygyapjas rend meglehetős pontossággal behatárolja az ábrázoltak körét: ebben az időszakban, 1792-ben a magyar politikai élet szereplői közül a király, a nádor és két további főrendű előkelőség volt a rend lovagja: 1782-től herceg erdődi Pálffy Károly József Jeromos (Bécs, 1735 - Bécs, 1816), majd 1790-től herceg galántai Esterházy Pál Antal (Bécs, 1738 - Bécs, 1794). 1792-ben mindkettőjük már a Magyar Királyi Szenti István Rend nagykeresztjét is birtokolta. Az üvegképen ábrázolt, az aranygyapjas és a Szent István rend jelvényeit is viselő két férfi viszont fiatal, azaz nem azonosítható a már 60 év körül járó két magyar föúr egyikével sem. Kizárásos alapon csak a fiatal király és a még éppen csak nagykorúvá lett nádor személye jöhet így szóba. Vö.: Liste nominale des chevaliers de l'ordre de la Toison d'or, depuis son institution jusqu'à nos jours, in: [Kanzlei des Ordens von Goldenen Vlies]: Das Haus Österreich und der Orden vom Goldenen Vlies. Leopold Stocker Verlag, Graz-Stuttgart 2007

10 1792-ben a Magyar Királyi Szent István Rend tagjai között még egy magyar főpap volt: pészaki Bajzáth József (Kissalló, 1720 - Veszprém, 1802) veszprémi püspök, aki 1767-ben a rend kiskeresztjét, majd 1777-ben a középkeresztjét kapta meg. A nagykeresztig tehát már nem jutott el, és egyébként is egészen más, szikárabb alkat volt, más arc- és orrformával. A rend tagjai között más püspök (és érsek) ekkor csak külföldi volt. L. Gödölle-Pallos szerk. i. m. (7. j.) 309-313

11 Vö.: 1792. évi VI. törvénycikk az országosan tett szabad ajánlatról. (http://www.1000ev.hu/index. php? $a=3 \&$ param $=4956$ )

12 A Bécsben, magyar nyelven kiadott, Görög Demeter (Hajdúdorog, 1760 - Bécs, 1833) és (Miskolczi) Kerekes Sámuel (Kiskunhalas, 1757 körül - Bécs, 1800) által szerkesztett folyóirat, a Magyar Hírmondó mögött ellenzéki főurakat, patrióta köznemeseket és volt jozefinistákat egyaránt találunk, de iránya mégis legközelebb a nemesi mozgalomhoz állt. Vö.: Kókay Györoy szerk.: A magyar sajtó története I. 1705-1848. Akadémiai Kiadó, Budapest 1979, 125.

13 Magyar Hírmondó. Költ Bétsben Szent IvánHavának (Júniusnak) 9-dik napján. 1792, 817-821.

$14 \mathrm{Az}$ országgyülés eseményeit pontosan végigköveti Szijártó M. István: A diéta. A magyar rendek és az országgyưlés 1708-1792. Balaton Akadémia Kiadó, Keszthely 2010, 64, 99, 123, 134, 358

15 Lajtai L. László: „Magyar nemzet vagyok”. Az első magyar nyelvû és hazai tárgyú történelemtankönyvek nemzetdiskurzusa. Argumentum, Budapest 2013, 34.

$16 \mathrm{Az}$ I. Ferenc király kezében tartott felirat alighanem a kép értelmezésének az egyik kulcsa. Éppen ezért a kiegészítésre szoruló, rövidített latin mondat megfelelő fordítását, feloldását - mint interpretációs javaslatot - külön is köszönöm Király Erzsébetnek.

17 Igaz ez akkor is, ha tudjuk, hogy a diétai tárgyalás nyelve is ez volt, és az országgyưlésen az uralkodóval latinul kellett a kapcsolatot tartani. Vö.: Szijártó i. m. (14. j.) 132-135.

$18 \mathrm{Az}$ országgyűlés helyszínéről egyébként ismerünk egykorú ábrázolást: a Bécsben kiadott Magyar Hírmondó 1792. 2. k. mellékleteként megjelent rézkarc az egykori országház Alsó- és Felsőtábla Termeinek perspektivikus hosszmetszeteit mutatja. Ez a két terem - a résztvevők nagy számára tekintettel - egyébként is hatalmas, sokablakos, karzatos ülésterem, nem pedig kisméretű szoba, mint a budapesti üvegképünkön ábrázolt helyiség. L. még http://epiteszforum.hu/buda-legregibb-balterme-aregi-orszaghaz-rekonstrukcios-tervei////21602.

19 A metszet-előképekről 1. a későbbiekben.

20 Ebből következően az sem valószínű, hogy az ábrázolás politikai gúnykép lenne, a rendi Magyarország maradiságának minden kellékét felvonultatva. Ezt a müfajt a korszak is ismerte, de megjelenési formáját - az olcsóbb előállítási költségek miatt természetes módon - a sokszorosított grafikában találta meg. Vö. G. Etényi Nóra: A nyomtatott információ értéke és funkcióváltozásai a kora újkorban. AETAS 27. évf. 2012. 4. szám, 122-143.

21 Ezt támasztja alá Rózsa György témánkba vágó ikonográfiai kutatásának végkövetkeztetése is: az országgyülési események megörökítése sem az uralkodó, sem a magyar főurak, sem az egyháziak számára nem volt kiemelten fontos: Rózsa György: Vázlat a magyar országgyülések ikonográfiájához. Folia Historica I. 1972, 88.

22 A 18. század végének és a 19. század elejének politikai eszmetörténetéról és a négy csoportba sorolható né- 
zetekről 1. részletesebben: Takács József: Modern magyar politikai eszmetörténet. Osiris, Budapest 2007, 14-21.

23 Érdekes hasonlóságok mutatkoznak e tekintetben a Szily János (Fel(ső)szopor, 1735 - Szombathely, 1799) szombathelyi püspök megbízásából Dorffmaister István (Pozsony, 1741 - Sopron, 1797) által 1792-ben megfestett Szent István-oltárképpel. Vö. Galavics Géza: Program és műalkotás a 18. század végén. Egy festmény születése és fogadtatása. (Múvészettörténeti Füzetek 2.) Akadémiai Kiadó, Budapest 1971, 38-39, 52-55.

24 Az üvegképeknek a hazai szakkutatás - nyilvánvalóan a csekélyebb magyar vonatkozások miatt - az eddigiekben kevesebb figyelmet szentelt. Az első és egyetlen átfogó munka a témában: Szacsvay Éva: Üvegképek. Néprajzi Múzeum - Vízió Müvészeti Alkotóközösség, Budapest 1996.

$25 \mathrm{Az}$ árnyképkészítés történetét már egy jó évszázada dolgozza fel a szakkutatás, így a szakirodalomban az egyes térségek sajátosságai is jobban megismerhetők. Vö. Ernst Biesalski: Scherenschnitt und Schattenriß. Kleine Geschichte der Silhouettenkunst. Callwey, München 1964; E. Nevill Jackson: Silhouettes: a history and dictionary of artists. Dover, New York 1981.

26 Biesalski i. m. (25. j.) 96. (A családi idill ábrázolása egyébként majd a biedermeier korszakában lesz általános, de első példáit már a 18. század végén megtaláljuk.)

27 A bécsi árnyképkészítés történetéről 1.: Gustav Gugitz: Altwiener Silhouettenschneider. Jahrbuch des Vereines für Geschichte der Stadt Wien I. 1939, 50-81.

28 Biesalski i. m. (25. j.) 85.

29 A klasszikus árnyképkészítés szempontjából ez már hanyatlás, hiszen mindez az árnykép lényegének ellentmondó folyamatot mutat, vö. Biesalski i. m. (25. j.) 45, ugyanakkor a müvészi eljárások ötvözése révén mégis értékes műalkotások készültek.

30 Johann Martin Will (1727-1806): A magyar királyi korona visszaadása 1790-ben (Országos Széchényi Könyvtár, Régi Nyomtatványok Tára, App. M. 360); ugyanennek a kismértékben eltérő változata Johann Hieronymus Löschenkohltól (Elberfeld, 1753 - Bécs, 1807) is ismert. Vö.: Reingard Witzmann: Hieronymus Löschenkohl. Bildreporter zwischen Barock und Biedermeier. Edition Tusch, Wien 1978, 25. képtábla.

31 Vö. Werner Telesko: Herrscherdarstellungen und Programmbilder. In: Monika Sommer Hrsg.: Hieronymus Löschenkohl. Sensationen aus dem alten Wien. (357. Sonderausstellung des Wien Museums.) Wien Museum, Wien 2009, 80-82. - Egyébként az 1780-as, 90-es évekből számos hasonló ikonográfiájú politikai eseményábrázolást ismerünk: Johann Martin Will: VI. Pius pápa és II. József császár találkozója Bécsben 1782 márciusában, 1782 („,Unterredung Pius VI. R. P. mit Joseph. II. R. K. zu Wien im März 1782"); Johann Hieronymus Löschenkohl: II. József tárgyalása VI. Piusszal, 1782 (Wien Museum, Inv.Nr. 62.034); Ismeretlen művész: Hollandia felosztását ábrázoló gúnyrajz, 1785 („Representation de cette estampe touchant les affaires d'Holland S. M. l'Empereur Jos. II. ..."), Bibliothèque nationale de France, département Estampes et photographie, RESERVE FOL-QB-201 [115]); Johann Hieronymus Löschenkohl: Az emsi kongresszus, 1787 („Der Congress in Ems”), (Wien Museum, Inv.Nr. 179.094); II. Lipót császár, Frigyes Vilmos porosz király és Frigyes Ágost szász választófejede- lem találkozója Pillnitzben 1791. augusztus 24-én, 1791 („Zusammenkunft Ihro Maj: des Kaisers Leopolds II. / Friedrich Wilhelms II. Königs von Preussen, und Friedrich August Churfürsten von Sachsen zu Pillnitz d: 24ten Aug. 791"), (Wien Museum, Inv.Nr. 108.475).

32 A Sommer Hrsg. i. m. (31. j.) 38-39. és 85. oldalain közölt képeken ugyancsak politikai eseményeket ábrázol, szobában, szimmetrikus elrendezésben, a középtengelytől két oldalra, egymással szembe forduló, ülő és álló alakokkal, a háttérben tükörrel, ablakokkal vagy képekkel.

33 Úgy tünik fel, hogy Löschenkohl számára a bonyolultabb üveghátlap-festés mint eljárás idegen volt, képeit inkább a gyorsabb technikák jellemezik. Vö.: Hieronymus Löschenkohl: 1753-1807. (Asstellungskatalog, Historisches Museum der Stadt Wien,) Wien 1959; Witzmann i. m. (30. j.), Sommer Hrswg. i. m. (31. j.); Thomas Hubmayer: Hieronymus Löschenkohl im Kontext der Kultur- und Sozialgeschichte des Josephinismus. Diplomarbeit, Universität Wien, Wien 2012.

34 Johann Ernst Mansfeld (Prága, 1738 - Bécs, 1796): II. Lipót magyar király koronázása (Országos Széchényi Könyvtár, Régi Nyomtatványok Tára, App. M. 113); Ismeretlen bécsi művész, 18. század vége: I. Ferenc koronázása Budán 1792. június 6. (Magyar Nemzeti Múzeum Történelmi Képcsarnok, MTKcs 10716); Mark Quirin (Littau, 1753 - Bécs, 1811): I. Ferenc magyar király a koronázási dombon (Országos Széchényi Könyvtár, Régi Nyomtatványok Tára, App. M. 142); I. Ferenc magyar király koronázási esküje (Országos Széchényi Könyvtár, Régi Nyomtatványok Tára, App. M. 143); Johann Ernst Mansfeld: Lovaggá ütés II. Lipót koronázásának napján (Országos Széchényi Könyvtár, Régi Nyomtatványok Tára, App. M. 114); Ismeretlen bécsi mester, 18. század vége (Artaria kiadása): I. Ferenc koronázási kardvágása Budán 1792. június 6. (Magyar Nemzeti Múzeum Történelmi Képcsarnok, MTKcs 1259); Johann Ernst Mansfeld: Mária Terézia királyné koronázása Budán 1792. június 10. (Magyar Nemzeti Múzeum Történelmi Képcsarnok, MTKcs 3035).

35 A korszak képi sajtótudósításait feldolgozó teljességre törekvő tanulmány sem ismer ilyen ábrázolást: D. Szemző Piroska: A magyar folyóirat-illusztráció kezdetei. In: Művészettörténeti Tanulmányok. A Magyar Müvészettörténeti Munkaközösség Évkönyve 1953. Budapest 1954, 101-184.oldal. A jelentősebb közgyüjtemények közül a Magyar Nemzeti Múzeum Történelmi Képcsarnok, az Országos Széchényi Könyvtár Régi Nyomtatványok Tára és a Budapesti Történeti Múzeum gyüjteményeit vizsgáltam. E helyütt is köszönöm Göldölle Mátyás muzeológus (Magyar Nemzeti Múzeum Történelmi Képcsarnok), valamint Farbaky Péter főigazgató és B. Nagy Anikó művészettörténész (Budapesti Történeti Múzeum) e téren nyújtott segítségét. Természetesen internetes adatforrásokat is vizsgáltam, különösen az Országos Széchényi Könyvtár irányításával és 48 magyar könyvtár - köztük a Budapest Gyüjteménye miatt itt kiemelten is fontos Fővárosi Szabó Ervin Könyvtár (Budapest) - összefogásával létrehozott Magyar Digitális Képkönyvtár (MDK) (http://www.kepkonyvtar.hu/), valamint a Hungaricana Közgyűjteményi Portál http://hungaricana.hu/hu/ adatbázisát.

36 A téma alapvető - az 1990-es évek közepéig megjelent - szakirodalmát közli Szacsvay i. m. (24. j.) 92-96. Az 
újabb szakirodalomból általános összefoglalásként ajánlható pl. Frieder Ryser - Yves Jolidon-Simone Bretz-RolfKeller - Uta Bergmann - Stefan Trümpler: Glanzlichter. Die Kunst der Hinterglasmalerei. Reflets enchanteurs. L'art de la peinture sous verre. (Schweizerisches Forschungszentrum zur Glasmalerei Romont) Benteli, Bern 2000. Ugyanakkor az interneten számos további szakirányú tanulmány címe, vagy akár teljes szövege is elérhető már. Ezeknek alapos összesítését adja a német kutatók által fenntartott www. hinterglasforschung.de internetes oldal.

37 Ryser et al. i. m. (36. j.) 270-271.

38 Heinrich Fuchs: Die österreichische Bildnisminiatur von den Anfängen bis zur Gegenwart. Wien 1981-1982, Bd 2 (L-Z), 43.

38 Heinrich Fuchs: Die österreichische Bildnisminiatur von den Anfängen bis zur Gegenwart. Wien 1981-1982, Bd 2 (L-Z), 43. 39 v1

39 E. Nevill Jackson: The History of Silhouettes. The Connoisseur, XXX. 1911, 32, 107. Az üvegkép fényképpel ellátott közlése és pontos leírása mellett meghatározására is kísérletet tesz: Andreas Strohammer: „Herr und Dame bei Jause". Eine Hinterglas-Silhouette von Ignaz Pfeilhauer? Bemerkungen zur Maltechnik und künstlerische Einordnung. Kunstjahrbuch der Stadt Linz 1994/95. 1995, 157-160.

40 A képet pontos leírásokkal és fekete-fehér, majd színes fényképfelvétellel együtt közli Friedrich Knaipp: Hinterglas-Silhouetten in und aus dem Land ob der Enns. In: Klaus Beitl - Franz Grieshofer [Bearb.]: Volkskultur, Mensch und Sachwelt. Festschrift für Franz C. Lipp. Wien 1978, 6. kép; Friedrich Knaipp - Wolfgang Brückner Hrsg.: Hinterglaskünste. Eine Bilddokumentation. Callway, Linz-München 1988, 117, 142. kép.

41 Strohammer i. m. (39. j.) 157-160.

42 L. a Bayerisches Fernsehen „Kunst \& Krempel” címü müsorának 2007. május 12-i adásában „Scherenschnitt - Um 1836, von Ignaz Pfeilhauer" címmel, http://www. br.de/fernsehen/bayerisches-fernsehen/sendungen/ kunst-und-krempel/schatzkammer/gemaelde/ schatzkammer-gemaelde-scherenschnitt100.html. Ez az üvegkép - igen tanulságos módon, mintha az idők nem is változtak volna - a 40 évvel korábbi mintát követi, csupán az árnyképes alakokon érződik a biedermeier stílusa.

43 2008. június 8-án került a bostoni (USA) Skinner cég American Furniture \& Decorative Arts címü árverésére, „Eglomise Gilt and Polychrome Painted Silhouette Portrait of a Gentleman, late 18th century" meghatározással az az üvegkép, mely annyira szoros hasonlóságokat, egyezéseket mutat az Andreas Strohammer által Pfeilhauernek tulajdonított üvegképpel (Strohammer i. m. [39. j.] 157-160.), hogy mögöttük azonos alkotót kell feltételeznünk. A Pfeilhauer neve alatt leírt közös jellemzők földrajzi kötődését erősíti az a tény is, hogy ugyancsak a Bajor Televízió (Bayerisches Fernsehen), „Kunst \& Krempel” című műsorának 2011. május 28-i adásában „Ein kunstvolles Silhouetten-Bild” címmel mutattak be egy palota belső terében olvasó férfit ábrázoló - véleményünk szerint ugyancsak Pfeilhauerre valló - üvegképet, mint helybeli, családi örökség darabját. (Az adásról részletesebben: http://www.br.de/fernsehen/ bayerisches-fernsehen/sendungen/kunst-und-krempel/ schatzkammer/kunst-auf-papier/kunst-und-krempelkunst-auf-papier-hinterglasmalerei100.html)
44 L. Strohammer i. m. (39. j.); Knaipp i. m. (40. j.) 219. A Bajor Televízió idézett (42. j.) adásában szerepelt Pfeilhauernek egy további, 1836-ra datált alkotása: http:// www.br.de/fernsehen/bayerisches-fernsehen/sendungen/ kunst-und-krempel/schatzkammer/gemaelde/ schatzkammer-gemaelde-scherenschnitt100.html

$45 \mathrm{Az}$ üveghátlapfestés szakkutatása „Pfeilhauer, Ignaz - Linz / Wien, um 1796 / Silhouettenmaler”, azaz 1796 körül Linzben és Bécsben működő árnyképfestőként jegyzi, mint akitől jelzett üvegképet is ismerünk, vagy egyéb módon adatolható az üvegképfestői működése. Vö.: Frieder Ryser: Verzauberte Bilder- Die Kunst der Malerei hinter Glas von der Antike bis zum 18. Jahrhundert. Klinkhardt \& Biermann, München 1991, 297.

46 A linzi városi plébánia anyakönyve szerint 1765. június 6-án született Ignaz Xaver Pfeilhauer, Franz Ferdinad és felesége, Anna Maria fiaként. 1800. június 2-án kötött házasságot Katharina Kristtel, majd a bejegyzés szerint 77 évesen, 1843. április 1-jén halt meg. L. Strohammer i. m. (39. j.) 160.

$47 \mathrm{Az}$ attribúciót illetően a teljesség kedvéért meg kell jegyeznünk, hogy általában a bécsi üveghátlap-festőkről aránylag keveset tudunk. Ismert tény ugyanis, hogy a 19. század első felének üvegművességét bemutató 1922es nagy bécsi üvegkiállítás külön fejezetet szentelt az üvegsziluettek és üveghátlap-festmények csoportjának (vö.: Hermann von Trenkwald: Ausstellung von Gläsern des Klassizismus, der Empire- und Biedermeierzeit. Beschreibender Katalog mit 39 Abbildungen. Österreichisches Museum für Kunst und Industrie, Wien 1922, 46-55.). Az itt - sajnos csak fénykép nélkül, leíró adatokkal - közölt üvegképek között több is akad, amely készítési kor és hely tekintetében egészen közeli analógia lehetne a budapesti üvegképhez. Ezek későbbi, fényképpel együtt történt közlését sajnos a szakirodalomban nem sikerült fellelni. (A magyar múkereskedelemben is kuriózumnak számított a közelmúltban a budapesti Nagyházi Galéria és Aukciósház 2015. május 20-i árverésén 766. tételszám alatt „Az első aeronauták emlékére, 1800 körül” címen árverésre bocsátott üvegkép. A „Fischer fecit” jelzéssel ellátott árnyképes és karcolt fémfóliás díszítésű üvegkép a bécsi Joseph Fischer [1762-1822] életművébe sorolható.) A bécsi Iparművészeti Múzeum (Österreichisches Museum für angewandte Kunst) üvegszakosztályának (Sammlung Glas und Keramik), valamint az üveghátlapfestés szakkutatása központjának számító svájci Vitrocentre Romont (Schweizerisches Forschungszentrum für Glasmalerei und Glaskunst) tájékoztatása szerint sem állapítható meg ennél több a korszak osztrák (polgári) üveghátlapképeiről. Külön köszönettel tartozom a Vitrocentre Romont üveghátlap-festéssel foglalkozó szakemberének, Yves Jolidonnak, aki az Ignaz Pfeilhauernek történő attribúciós feltevésemet - hosszas levélváltások során - megerősítette.

48 Knaipp i. m. (40. j.) 219. ugyan közöl egy adatot, miszerint Ignaz Pfeilhauer három jelzett művét ismerjük, s ezek között említ két datált munkát: 1792-es és 1796-os dátummal, ugyanakkor pár lappal később a részletes leírással és fényképpel közölt alkotásai között már 1794-es és 1796-os jelzetü üvegképeket mutat be. (Feltehetően a szöveges részben megadott 1792-es dátum lehetett elírás, vö.: Knaipp-Brückner Hrsg. i. m. [40. j.], 117. oldal, 142143. képek, 1794 és 1796.) 


\section{FIDELIS PANNONIA - LOYAL PANNONIA. POLITICAL PROGRAMME ON REVERSE GLAS PAINTING BY IGNAZ PFEILHAUER FROM 1792}

The subject of the paper - a reverse glass painting (Hinterglasmalerei) - came to its current owner from a well-known private collection in Budapest. Painted on a 2 mm thick glass plate measuring $300 \times 350 \mathrm{~mm}$, silhouettes of figures with subtly painted details on their costumes are shown with scratched metal foil decoration in the background. The date of making around 1790 is clearly determined by the depicted scene in addition to the neo-classical late baroque style of the rendering. The Hungarian style clothing of the figures, their badges and the Hungarian coat of arms on the breast of the Habsburg eagle together with the inscriptions ("Fidelis Pannia", "Ego Fidelis Natio Hungarica") provide first-hand clues for interpretation. From among the rulers of the age, the "F II" monogram seen at two places must refer to Francis II, Holy Roman Emperor and king of Bohemia, who ascended the Hungarian throne as Francis I in 1792. The young man standing on the right is to be identified with him on account of the Order of the Golden Fleece and the Hungarian Royal Order of St Stephen worn on his attire. The young man sitting on left must then be the Hungarian palatine Alexander Leopold. The elderly high priest standing behind him also wearing the decorations of the grand cross of the Order of St Stephen is archbishop of Esztergom Count József Batthyány. The young female figure in Hungarian style costume is the queen, Maria Teresa of the Two Sicilies. The picture shows the most important figures of the compromise arrived at during the Diet of 1792 held in the ancient Hungarian capital Buda.

In contradistinction to the legacy of the late Joseph II (died 1790) who had imposed reforms, this political settlement promised to restore the ancient constitution of the Hungarian nobility in return for an offer of taxes and recruits needed for the Habsburgs' French wars. This agreement was particularly well received by the rural Hungarian nobility. The choice of the language for the inscriptions - Latin - also confirms this as a conserving cultural symbol. The person who ordered the picture and first owned it must be sought in this social stratum.

The date of making must be connected to the Diet of 1792, for the significance of the compromise was soon overshadowed by the events of the French wars and oth- er domestic political changes, so the subject of the picture had no topical significance in the mid-1790s any more. The glass picture was certainly made in Vienna. This technique was not practiced in Hungary; Vienna was a centre of silhouette painting at that time. Silhouettes already appeared painted on glass, alloyed with other techniques. The pictorial devices of the picture also point towards Vienna, reminding one of the widely disseminated silhouette scenes of Johann Hieronymus Löschenkohl (Elberfeld, 1753 - Vienna, 1807). In this circle one can find a glass painter of Linz, Ignaz Pfeilhauer (Linz, 1765 - Linz, 1843), who also worked in Vienna and several of whose signed pictures are known by research. Outstanding among them are a signed picture dated 1796 showing the chamber orchestra of the Linz civil guard in green uniform and an unidentified family scene at the breakfast table, a reverse glass painting from 1794. After a comparison with further pictures by him, it can be concluded that the Budapest glass painting displays the same peculiarities: in the group scenes set in interiors the somewhat rigidly rendered silhouette figures appear to be floating, and the lines of the floor and the symmetrically placed pieces of furniture refuse to proceed towards a vanishing point, running counter to the rules of perspective. The body and hand postures of the conversing silhouette figures with inner details also drawn in gold and other colours are similar in all paintings concerned. This is complemented with techniques of colorfully painted and scratched metal foil, canvas and paper applications. On the basis of all this the Budapest reverse glass painting may be defined as the earliest known work of Ignaz Pfeilhauer. BUZINKAY Péter, Forster Gyula Nemzeti Örökségvédelmi és Vagyongazdálkodási Központ Mütárgyfelügyeleti Iroda (Inspectorate of Cultural Goods / Gyula Forster National Centre for Cultural Heritage Management)

Kulcsszavak: üveghátlapfestmény, árnykép, II. Ferenc osztrák császár (I. Ferenc magyar király), 1792, magyar országgyűlés, Ignaz Pfeilhauer / Keywords: reverse glass painting, silhouette picture, Emperor Francis II (Hungarian king Francis I), 1792, Buda, Diet, Ignaz Pfeilhauer 